\title{
Research on College English Reading Teaching Based on CBI Teaching Concept
}

\author{
Li Meijing \\ Foreign Language Department \\ Jilin Business and Technology College \\ Changchun, China \\ 182076127@qq.com
}

\begin{abstract}
With the emphasis on the English language application ability, CBI teaching philosophy based on content attracts more and more attention of education. The ultimate goal of CBI concept isn't teaching, but regards language as a tool to teach all kinds of knowledge and let learners acquire not only academic knowledge but also linguistic knowledge at the same time. In view of the problems existing in current college English reading teaching and foreign language talents cultivation, it is an effective way to cultivate applied talents to introduce CBI into English reading teaching, which can not only fully meet the different needs of the students' learning, but also can effectively expand students' knowledge and cultivate students' comprehensive quality.
\end{abstract}

Keywords-CBI teaching concept; college English; reading teaching; comprehensive quality; applied talents

\section{INTRODUCTION}

Listening and speaking ability is an important part in the application of English language, and it is also the basic requirement of the society for talents. At present, talents cultivated by universities in our country still have a certain distance from talents meeting international society needs. How to cultivate college students in our country meeting international needs mainly lies in the strong professional ability of talents, placing them in an invincible position in the international arena. College English teaching method has become the main research topic of college English teaching in our country. The aim is to improve the quality of English teaching, to cultivate the talents with high skill and to adapt to the economic development of our country and the development of international talents. CBI teaching philosophy is constantly being pursued by the domestic and foreign college English teaching and learning.

\section{CBI TEACHING CONCEPT AND ITS BENEFITS}

Content-based instruction (CBI) is a significant approach in language education ${ }^{[1]}$. CBI is designed to provide secondlanguage learners instruction in content and language. The CBI approach is comparable to English for Specific Purposes (ESP), which usually is for vocational or occupational needs or English for Academic Purposes (EAP). The goal of CBI is to prepare students to acquire the languages while using the context of any subject matter so that students learn the language by using it within the specific context. Rather than learning a language out of context, it is learned within the context of a specific academic subject. There are some benefits of CBI approach.

TABLE I. BENEFITS OF CBI APPROACH ${ }^{[2]}$

\begin{tabular}{|c|c|}
\hline a. & $\begin{array}{l}\text { - Learners are exposed to a considerable amount of language } \\
\text { through stimulating content. Learners explore interesting content } \\
\text { and are engaged in appropriate language-dependent activities. } \\
\text { Languages are not learned through direct instruction, but rather } \\
\text { acquired "naturally" or automatically. }\end{array}$ \\
\hline b. & $\begin{array}{l}\text { - CBI supports contextualized learning; learners are taught } \\
\text { useful language that is embedded within relevant discourse } \\
\text { contexts rather than as isolated language fragments. Hence } \\
\text { students make greater connections with the language and what } \\
\text { they already know. }\end{array}$ \\
\hline C. & $\begin{array}{l}\text { Complex information is delivered through real life context } \\
\text { for the students to grasp well and leads to intrinsic motivation. }\end{array}$ \\
\hline d. & $\begin{array}{l}\text { - In CBI information is reiterated by strategically delivering } \\
\text { information at right time and situation compelling the students to } \\
\text { learn out of passion. }\end{array}$ \\
\hline e. & $\begin{array}{l}\text { - Greater flexibility and adaptability in the curriculum can be } \\
\text { deployed as per the student's interest. }\end{array}$ \\
\hline
\end{tabular}

From a theoretical point of view, CBI directly integrates research results in the following several areas.

\section{A. Study of Second Language Acquisition}

Second language acquisition scholars believe that when the second language learning condition is same as or similar to that of mother tongue acquisition, language learners can achieve the greatest success. That is to say, when the teaching is concerned with meaning rather than form, when the language input is to cultivate students' ability, when students have no anxiety in language learning and when students have full access to language and use language meaningfully, language learning can achieve great success. In the classroom, when the target language is a kind of communication media and not the object of analysis, students' language ability can reach a higher level. CBI teaching, to meet all of the above conditions, should consider the students' language ability, demand, interest and professional knowledge level ${ }^{[3]}$. CBI teaching content is the academic content and not the linguistic knowledge, so students need not pay attention to grammar and remember new words deliberately, but are supposed to participate in the discussion and theme related reading and acquire a lot of knowledge of language in the process. 


\section{B. Cooperative Learning Research}

Research shows that cooperative learning can provide students with more opportunities to participate so that students can use the target language in a relatively relaxed environment. Cooperative learning also provides a platform for students to conduct a higher level of learning and thinking and gives greater support to enhance their self-confidence and learning motivation. CBI teaching enables students to share the responsibility and complete the task of teaching through the method of collective learning discussion. What has been widely used as CBI teaching methods includes group collective learning, complementary reading and peer correction. These teaching methods can provide students with a large number of opportunities to sufficiently contact with each other, exchange ideas, involve in hypothesis testing and construct knowledge.

\section{Extensive Reading Research}

Related research shows that extensive reading can improve the language ability of students and expand their knowledge field. Research shows that extensive reading can not only help students become better readers and writers, enlarge their vocabulary and improve their listening and speaking ability, but also can enhance the students' confidence and motivation. Reading is a part of the CBI teaching, so the students need to read a lot of reading materials involved in and related to learning content. In CBI teaching, the teaching material is not the only material for students to use. Cartoon books, magazines, advertisements all belong to learning materials. Using a variety of different types of reading materials can not only enable students to contact different types of discourse, but also allow them to contact a variety of information resources. One of the main purposes of CBI is to encourage students to encourage students' independence and expand the available information beyond classroom and allow students to choose their own learning materials, which helps to improve students' reading ability.

\section{Motivation and Interest Research}

Research shows that motivation partially deems from learners' interest in the knowledge they are actually learning, the learners' understanding of the knowledge value and the sense of achievement brought to the learners through various efforts and challenges. CBI teaching, therefore, aims to meet the needs and interests of learners. The curriculum is set up based on the learners' interests, actual needs and future work, so the learners can have strong learning motivation in the learning process and the learning effect can be self-evident. A large number of English teaching researches have proved that CBI teaching can make learners be greatly improved in terms of language ability and knowledge content of each subject. Kasper's research shows that students who take part in the CBI program can achieve significantly higher score than those who have not participated in foreign language reading tests and foreign language courses. Many experts and scholars have conducted a lot of researches and reports on the CBI teaching effect. It has been proved that the CBI teaching method can effectively improve the language ability and discipline knowledge level of the learners. The language proficiency of students who have received CBI courses is significantly better than those who haven't participated in the course.

Moreover, students who have received CBI courses can possibly achieve great benefits in the second language learning. Many domestic experts and scholars have made a lot of researches on CBI teaching theory and have achieved good results. From the domestic and foreign researches on theory and practice, the advantages of CBI teaching concept are more significant than other teaching methods. Content based instruction also shows the development of students' language ability, which can broaden students' knowledge and has great potential to improve the comprehensive quality of students.

\section{CURRENT SituAtion OF COLlEGE ENGLish READING TEACHING IN CHINA}

English Teaching Syllabus of higher schools in China (hereinafter referred to as "Syllabus") calls for setting English courses in Grade One or Two for English majors, including listening, speaking, reading, writing, pronunciation and grammar, and the purpose is to help students master five kinds of language skills and further lay a solid foundation for English language learning. According to the "Syllabus" provisions, the English reading course aims to cultivate students' English reading comprehension ability, improve students' reading speed, cultivate students' ability to observe language and logical thinking ability including judgment, hypothesis analysis, inductive reasoning test, improve students' reading skills, including reading, skimming and referring and help students enlarge their vocabulary and absorb language and cultural background knowledge through reading training ${ }^{[4]}$. Thus it can be seen that cultivating English reading comprehension ability is one of the important goals in the course of English reading.

The teaching emphasis of English major in local colleges is to train students' ability of reading comprehension and reading speed, so as to improve students' reading ability and English level. The usual practice of teaching English reading course is to introduce the background knowledge of the related articles, explain the reading skills, organize the students to read the articles and do all kinds of exercises provided by the teaching materials. However, this kind of teaching mode is facing a great challenge for many years. A lot of students lose interest in English reading class, and there is a great distance between the teaching effect and the expected value. The main reason is that local universities, based on the "Syllabus" provisions, mostly choose appropriate reading materials which lack of systematic and coherent content. Compared with other nonEnglish majored language teaching, English reading topics and content can only stay on the surface. What should be firstly concerned is the reading skills training in English reading class rather than focus on the content of teaching. The content involved in reading teaching is difficult to maintain the students' interest in learning and stimulate and maintain students' learning motivation for a long time. Local colleges, as the main base for training talents for the society, should focus on the cultivation of English talents. While the traditional English teaching focuses on the impartment of English knowledge, such as written English exercises, thus, students' English learning excessively relies on grammatical knowledge. Once they are need in oral practice, they will fully expose the 
defects of the traditional English teaching, which also makes students lose the competitiveness in the international arena. Therefore, it is necessary to attach importance to the application of CBI teaching concept in Chinese universities.

\section{THE APPLICATION OF CBI TEACHING THEORY IN ENGLISH TEACHING IN LOCAL COLLEGES IN CHINA}

The local colleges in our country cannot be compared with the first-class universities both at home and abroad in teaching staff and teaching facilities. So how to apply CBI teaching concept in English teaching in colleges and improve the quality of English teaching can be elaborated mainly from the following aspects.

\section{A. Combined with the Actual Situation}

Colleges of our country lack of English teaching staff and there are various teaching tasks to face at present, which inevitably leads to all kinds of contradictions and conflicts. As a matter of course, development of English teaching is stagnant at present. Because the teaching mode and teaching concept are not in the forefront and the exam oriented education still plays a dominant role, students are stuck in an embarrassing situation, namely, they fail to express fluently. In order to solve this problem, CBI teaching method is the most suitable approach for college English teaching reform in China, which enables English teaching not only to learn language, but also to integrate professional knowledge into life and bring a pleasure for the boring language learning at present. Students can learn to solve language problems encountered in real life, realize the importance of cognition of language learning and stimulate their enthusiasm in learning, laying a good foundation for the study of professional knowledge in the future.

\section{B. Teaching Material Reform}

American education mode has led to modern education thought, and the formation of modern education thought in return has important significance for the development of CBI teaching. At present, the development of teaching materials views students as the core, starting from the actual situation of the students and making the teaching material content more fit for the actual situation. In the CBI teaching philosophy, it is advocated to use original materials in English teaching in colleges because the original materials can not only render more authentic language materials, but also maximize students' learning ability and lay a good foundation for students wanting to study abroad. For the study of any course, the selection of teaching materials is very important in that it directly affects the teaching effect, especially the extremely serious impact on the CBI teaching mode. For example, in the media, clinical medicine, physics and other disciplines, the use of CBI teaching mode should select original materials in order to enable students to understand the latest scientific research results and scientific trends. Compared with the domestic textbooks, the original textbook is more interesting, which is not only rich and colorful, but also has a variety of regulations, helping to obtain the knowledge of English language and obtain professional knowledge. Language is the tool of communication system, so in the process of compiling, we must firstly pay attention to the systematic teaching content, which is easy to exchange and has certain recognition. Secondly, the textbook should respect the memory characteristics of students and pay attention to the harmony and unity of teaching science and interest. Along with the science and technology changing rapidly, the social development needs a person not only to simply understand science and technology, but to develop a full range of knowledge involved in related fields, so the textbook should be compiled to keep up with the pace of updating of knowledge, which requires teachers to constantly update their teaching knowledge and idea based on CBI teaching concept.

\section{Focusing on Training}

The powerful teaching staff largely relies on training. No matter how education reforms and develops, teacher always plays an irreplaceable role, so college English teaching based on CBI teaching concept should pay attention to training teaching staff. In university, there are many young teachers with good English foundation and professional ability, and the school should make full use of the teachers, so these teachers should be trained in English regularly. The training process should only be combined with the professional expertise of teachers instead of simply carrying out language training. Taking the teachers' task into account, colleges can arrange the training courses during holidays. China took the lead in the implementation of CBI teaching philosophy and has made some achievements in high education teaching. After receiving training courses, teachers can be evaluated comprehensively in terms of their qualification to carry out the CBI teaching.

\section{The Balance between Teachers and Students}

When the colleges in China implement CBI teaching philosophy, they should make full use of the resources foreign teachers and employ some foreign teachers with professional English ability contributing to the application of CBI teaching philosophy in college English teaching. The premise of quality education is focused on students. Accordingly, CBI teaching mode is no exception to consider the personality of students. Through the understanding of students personality, ability and interest, it is able to carry out CBI teaching mode more easily, which not only helps to improve the effect of English teaching, but also helps to improve students' learning ability ${ }^{[5]}$. The comprehensive training of foreign language and professional subjects is the direction of talents training in our country and the world. English, as a kind of communication tool, is bound to be unable to cultivate the talents of the society if it is separated from the professional knowledge ${ }^{[6]}$. At present, one of the purposes of the CBI teaching concept in domestic and foreign universities is to cultivate the students to be the compound talents with the social development. CBI teaching concept has opened up a new teaching way for College English teaching at home and abroad.

\section{CONCLUSION}

The development of language is to serve the society, which the nature of language, so language education must keep pace with the times, cultivate more talents for the society and make contribution to social development and human development. CBI teaching theorists believe that when learners regard 
language as a means to obtain information rather than the ultimate purpose of language learning, language learning will be more successful. CBI teaching can better meet the needs of students for language. So, in view of the English reading teaching problems in current local college, the introduction of CBI teaching theory can effectively help local colleges improve the quality of English reading teaching, successfully complete the "Syllabus" provisions, be conducive to the expansion of students' employment and cultivate applied talents of foreign languages.

\section{REFERENCES}

[1] College foreign language steering committee English group. English Teaching Syllabus for English Majors in Colleges[M].Shanghai: Shanghai Foreign Language Education Press, 2000

[2] Krashen, S. Sheltered Subject Matter Teaching[J].Cross-Currents , 1991( 18)

[3] Kasper, L. Improved reading performance for ESL students through academic course pairing[J]. Journal of Reading, 1994(37)

[4] Brinton D M, Snow M A \& Wesche M B. Content-Based Second Language Instruction [M]. New York: Newbury House,1999

[5] Grabe W \& Stoller F L. Content-based Instruction: Research Foundations [C]. In Snow M A \& Brinton D M (eds.), The ContentBased Classroom: Perspectives on Integrating Language and Content. London: Longman,1997.

[6] Mohan B. Language and Content. Reading [M]. MA: Addison- Wesley Publishing Company,1986 